\title{
Pemenuhan Hak Asasi Manusia Atas Bangunan Dengan Kontrak Built, Operate And Transfer
}

\author{
Sarah Selfina Kuahaty \\ Dosen Fakultas Hukum Universitas Pattimura, Ambon, Indonesia \\ E-mail: selfikuahaty@gmail.com
}

\begin{abstract}
One of the goals of the state as mandated by the Constitution NRI Year 1945 is to promote the general welfare. As mandated by the constitution, the government is obliged to meet the objectives of the country. In addition Article 28 paragraph 1 of the Constitution NRI 1945 also gives the right to every person to live in physical and spiritual prosperity, as a human right. One form of the welfare of society is the availability of infrastructure and facilities to support each activity. The realization of infrastructure facilities such example is building. On one hand the government does not have the funds to provide the building, but the government owns the land. Therefore, the government can invite investors and cooperation for the procurement of the building by using the System Build, Operate and Transfer.
\end{abstract}

keywords: Human Rights, BOT Contract

\section{A. PENDAHULUAN.}

Pemerintah memiliki tugas dalam penyelenggaraan negara untuk kepentingan masyarakat, berupa terpenuhinya berbagai kebutuhan dasar untuk mencapai kesejah- teraan umum. Tugas negara ini merupakan tuntutan dari adanya perkembangan konsep negara hukum yang tidak hanya sebagai negara penjaga malam (nachtwachterstaat) untuk menjaga ketertiban dan ketentraman.

Perkembangan negara hukum dengan meninggalkan konsep negara penjaga malam (nachtwachterstaat) didasari pada perkembangan negaranegara Eropa yang mengalami krisis ekonomi setelah Perang Dunia II yang melahirkan konsep negara kesejahteraan. Menurut Philipus M. Hadjon ${ }^{1}$, bahwa : "Didorong oleh krisis ekonomi setelah Perang Dunia II, lahirlah konsep "welvaartsstaat" yang kemudian lebih dikenal dengan istilah "verzorgings-

\footnotetext{
${ }^{1}$ Philipus M. Hadjon, Perlindungan Hukum Bagi Rakyat di Indonesia, Sebuah Studi tentang Prinsip-Prinsipnya dan Penanganannya oleh Pengadilan Dalam Lingkungan Peradilan Umum dan Pembentukan Peradilan Administrasi, Edisi Khusus, Penerbit Peradaban, Cet. Pertama, 2007, h. 72.
} 
staat".

Welvaartsstaat

dan

verzorgingsstaat merupakan konsepkonsep sosiologi dan politikologi. Dalam konsep yuridis, A.M. Donner berpendapat bahwa istilah "sociale rechtsstaat" lebih baik daripada istilah "welvaartsstaat".

Konsep negara hukum kesejahteraan sebagai terjemahan dari bahasa Belanda "welvaartsstaat" sebagaimana dikemukakan di atas, pada hakekatnya lebih diarahkan dalam pendekatan sosial sebagai akibat dari dampak Perang Dunia II yang menimbulkan berbagai krisis sosial karena terjadi pengangguran besarbesaran, kekurangan pangan dan gizi dan sebagainya. Dalam pendekatan hukum, maka negara hukum kesejahteraan merupakan terjemahan dari istilah "sociale rechtsstaat" atau yang disebut dengan "sociale democratische rechtsstaat".

Melalui konsep sociale rechtsstaat, pemerintah dituntut untuk memajukan kesejahteraan umum. Perkembangan ini pun sesuai dengan Pembukaan Undang-Undang Dasar Negara Republik Indonesia Tahun 1945 alinea keempat yang menyatakan bahwa : ".....Negara Republik Indonesia bertujuan untuk melindungi segenap bangsa Indonesia dan seluruh tumpah darah Indonesia, memajukan kesejahteraan umum, mencerdaskan kehidupan bangsa...". Rumusan tujuan negara di atas tentunya memiliki kesamaan dengan tujuan yang diharapkan dari konsep sociale rechtsstaat.

Tujuan pembangunan nasional adalah mewujudkan suatu masyarakat yang adil dan makmur, merata baik material maupun spiritual. Negara yang berlandaskan Pancasila dan UndangUndang Dasar Negara Republik Indonesia Tahun 1945 dalam wadah Negara Kesatuan Republik Indonesia yang merdeka, bersatu, berdaulat, adil dan makmur. Usaha untuk mewujudkan tujuan nasional, pembangunan di segala aspek kehidupan merupakan hal yang penting.

Pembangunan tidak hanya dilakukan diberbagai bidang tertentu saja, tapi pada berbagai bidang yang meliputi segala aspek kehidupan, yaitu pembangunan di bidang politik, ekonomi, sumber daya alam, sumber daya manusia, budaya, pertahanan dan keamanan.

Salah satu sumber daya alam yang sangat penting adalah tanah. Tanah sebagai penopang kehidupan bagi masyarakat sebagai tempat untuk hidup dan dapat dimanfaatkan untuk memenuhi kebutuhan masyarakat dengan aktivitas ekonomi terhadapnya. Secara khusus, bagi pemerintah daerah untuk meningkatkan perekonomian masyarakat di daerah dilakukan dengan memberdayakan sumber daya alam yang ada di daerah, berupa tanah dengan membangun fasilitas-fasilitas umum demi kepentingan masyarakat seperti sarana pendidikan, transportasi, pelabuhan, perhubungan dan lain-lain.

Pemanfaatan tanah untuk pembangunan fasilitas-fasilitas umum yang dilakukan oleh pemerintah sering melibatkan pihak ketiga. Pelibatan pihak ketiga ini untuk membantu pemerintah daerah dalam penyediaan fasilitasfasilitas umum dimaksud, oleh karena pemerintah daerah tidak atau belum memiliki anggaran untuk membangunnya. Untuk itu, pemerintah sering menggunakan kerjasama penyertaan modal dalam bentuk Built, Operating, and Transfer (selanjutnya disingkat BOT) yang dilaksanakan berdasarkan Kontrak BOT.

BOT merupakan salah satu alternatif pembiayaan proyek yang dapat dilakukan dengan mengundang pihak swasta untuk berpartisipasi dalam pengadaan proyek pemerintah. Dengan BOT, sektor swasta berperan dalam hal mendesain, menyedia- kan keuangan, membangun dan meng- operasikan fasilitas untuk kemudian akhirnya, setelah masa konsesi tertentu, 
kepemilikan ditransfer kepada pemilik tanah atau pemerintah. Oleh karena itu, BOT dapat dimaknai sebagai teknik untuk mengem- bangkan proyek-proyek infrastruktur dengan menggunakan inisiatif dan pendanaan dari pihak swasta.

Kontrak BOT di satu sisi memberikan kemudahan kepada pemerintah dengan adanya prinsip saling menguntung- kan, namun pada sisi lain pun akan membawa permasalahan terkait dengan aspek penyerahan kembali tanah dan bangunan komersial. Dalam waktu konsesi tertentu yang diberikan, pengoperasian bangunan komersial dimaksud telah dilaksanakan oleh pihak pelaksana proyek atau pihak swasta. Tentu saja dalam pengoperasian bangunan komersial dimaksud, nilai bangunan komersial tidak lagi sesuai dengan nilai bangunan sebelumnya dan malahan mengakibatkan bangunan rusak dan sebagainya.

Fakta ini dapat dilihat di Kota Ambon dengan adanya sistem BOT terhadap bangunan komersial Ambon Plaza yang saat ini dioperasikan oleh PT. Modern Multi Guna. Dengan waktu pengoperasian yang terbatas, bangunan komersial Ambon Plaza ini telah mengalami kerusakan baik di dalam maupun di luar bangunan. Proses transfer barang sebagai bagian akhir dari kontrak BOT, tidak serta merta pihak ketiga akan menyerahkan bangunan dimaksud dalam kondisi yang tidak sesuai lagi dengan peruntukkannya.

Bangunan Pasar yang diserahkan oleh pihak ketiga kepada Pemerintah Kota Ambon tidak semata-mata digunakan untuk kepentingan aktivitas penyelenggaraan pemerintahan oleh pemerintah. Namun, bangunan yang diserahkan merupakan bangunan untuk kepentingan masyarakat. Tentunya, kerusakan bangunan yang tidak dapat dinikmati oleh masyarakat merupakan pelanggaran terhadap hak asasi manusia untuk mendapatkan, memanfaatkan dan menikmati fasilitas publik yang nyaman dan aman.

\section{B. PEMBAHASAN}

\section{Penyelenggaraan Kontrak BOT}

Pemerintah selaku pelaku hukum keperdataan (civil actor) dalam melaksanakan perbuatan hukum keperdataan (privaatrechtelijke handelingen) nampak dalam berbagai hubungan kontraktual dalam bentuk pengadaan barang dan jasa. Pengadaan barang dan jasa dilakukan oleh pemerintah dalam menjalankan fungsi penyelenggaraan negara. Dalam kaitan ini, pemerintah mengikatkan diri dalam hubungan kontraktual dengan sektor swasta yakni dengan mengikatkan diri ke dalam suatu kontrak pengadaan barang dan jasa. Hubungan kontraktual yang dibentuk oleh pemerintah ini juga terkait dengan kewajiban untuk menyediakan, membangun dan memelihara fasilitas umum (public utility). ${ }^{2}$

Ketika pemerintah bertindak dalam lapangan keperdataan dan tunduk pada peraturan hukum perdata, pemerintah bertindak sebagai wakil dari badan hukum, bukan wakil dari jabatan. Oleh karena itu, kedudukan pemerintah dalam pergaulan hukum keperdataan tidak berbeda dengan seseorang atau badan hukum privat, tidak memiliki kedudukan yang istimewa, dan dapat menjadi pihak dalam sengketa keperdataan dengan kedudukan yang sama dengan seseorang atau badan hukum perdata (equality before the law) dalam peradilan umum.

Pemerintah melaksanakan hubungan kontraktual dengan pihak swasta lebih berkaitan dengan pekerjaan di bidang infrastruktur. Menurut Juoro Umar, pemerintah mengembangkan jasa

\footnotetext{
Yohanes Sogar Simamora, Hukum Perjanjian - Prinsip Hukum Kontrak Pengadaan Barang dan Jasa Oleh Pemerintah, LaksBang PRESSindo, Yogyakarta, 2009, h. 2.
} 
pelayanan infrastruktur publik melalui

kerjasama dengan pihak swasta dibutuhkan karena: ${ }^{3}$

1. Permintaan lebih cepat dibandingkan dengan kemampuan Pemerintah dalam menyediakan jasa pelayanan infrastruktur;

2. Kebutuhan investasi yang sangat besar tidak dapat dipenuhi oleh Pemerintah saja, hanya sekitar $50 \%$ dari perkiraan investasi prasarana dapat terpenuhi APBN, keuntungan BUMN, dan bantuan pembangunan dari luar negeri;

3. Kerja sama pihak swasta memberikan tambahan sumber pendanaan prasarana dan kemampuan manajerial yang baik;

4. Dalam rangka persaingan global, kemitraan Pemerintah dan swasta dapat mempercepat penyediaan infrastruktur sekaligus meningkatkan efisiensi kualitas jasa pelayanan;

5. Pembangunan infrastruktur harus diperlakukan sebagai kegiatan bisnis;

6. Menciptakan paradigma baru dalam penyediaan jasa pelayanan infrastruktur dari monopoli ke suatu model kompetitif;

7. Melindungi kepentingan umum.

Semakin pesatnya perkembangan sektor bisnis menyebabkan kebutuhan akan modal semakin besar. Di satu sisi ada pihak yang kekurangan modal, sedangkan di sisi lain ada pihak yang kelebihan modal. Untuk menyalurkan modal pada pihak yang memerlukan diperlukan kerja sama penyertaan modal sebagai alternatif pembiayaan yang sering digunakan oleh pelaku ekonomi.

Bentuk kerja sama penyertaan modal antara lain:

a. Sewa Guna Usaha (Leasing)

Istilah leasing sebenarnya berasal dari kata lease, yang berarti sewa menyewa. Karena memang dasarnya leasing adalah sewa menyewa. Dalam bahasa Indonesia,

3 Juoro Umar, Peran Swasta dan Kepentingan Masyarakat Dalam Pembangunan Infrastruktur, Koperasi Jasa Profesi, Jakarta, 1997, h. 140. kata leasing sering diistilahkan dengan sewa guna usaha. ${ }^{4}$ Sewa Guna Usaha dilakukan dalam bentuk pengadaan barang modal dari Penyewa Guna Usaha (Lessee), baik dengan maupun tanpa hak opsi untuk membeli barang tersebut. Dalam kegiatan Sewa Guna Usaha, pengadaan barang modal dapat juga dilakukan dengan cara membeli barang milik Penyewa Guna Usaha (Lessee) yang kemudian disewa gunakan kembali. Sepanjang perjanjian Sewa Guna Usaha masih berlaku, hak milik atas barang modal objek transaksi sewa guna usaha berada pada Perusahaan Sewa Guna Usaha (Lessor). ${ }^{5}$

b. Anjak Piutang

Anjak piutang merupakan usaha pembiayaan dalam bentuk pembelian dan/atau pengalihan serta pengurusan piutang atau tagihan jangka pendek dari suatu transaksi perdagangan dalam dan luar negeri.

c. Modal Ventura (Capital Venture)

Dalam Keputusan Presiden Nomor 61 Tahun 1988 tentang Lembaga Pembiayaan, modal ventura merupakan salah satu bidang usaha dari lembaga pembiayaan. Modal ventura (capital venture) merupakan kegiatan pembiayaan dalam bentuk penyertaan modal ke dalam suatu Perusahaan Pasangan Usaha (Investee Company) untuk jangka waktu tertentu, tidak melebihi jangka waktu 10 (sepuluh) tahun. Kegiatan Modal Ventura dilakukan dalam bentuk penyertaan modal ke dalam suatu Perusahaan Pasangan Usaha (Investee Company) untuk:

4 Munir Fuady, Hukum Tentang Pembiayaan Teori dan Praktek, PT. Citra Aditya Bakti, Bandung, 1995, h. 7.

${ }^{5}$ Lihat Keputusan Menteri Keuangan Republik Indonesia Nomor 1251/KMK/1988 tentang Ketentuan dan Tata Cara Pelaksanaan Lembaga Pembiayaan 
1. pengembangan suatu penemuan baru;

2. pengembangan perusahaan yang berada pada tahap pengembangan;

3. membantu perusahaan yang berada pada tahap pengembangan;

4. membantu perusahaan yang berada dalam tahap kemunduran usaha;

5. pengembangan proyek penelitian dan rekayasa;

6. pengembangan pelbagai penggunaan teknologi baru, dan alih teknologi baik dari dalam maupun luar negeri;

7. membantu pengalihan pemilikan perusahaan. $^{6}$

d. Pembiayaan Konsumen

Keputusan Menteri Keuangan Nomor 1251/KMK.013/1988 tentang Ketentuan dan Tata Cara Pelaksanaan Lembaga Pembiayaan memberikan pengertian pembiayaan konsumen sebagai suatu kegiatan yang dilakukan dalam bentuk penyediaan dana bagi konsumen untuk pembelian barang yang pembayarannya dilakukan secara angsuran atau berkala oleh konsumen.

e. Bangun Guna Serah (Built, Operation and Transfer/BOT)

BOT adalah sistem pembiayaan (biasanya diterapkan proyek pemerintah) berskala besar yang dalam studi kelayakan pengadaan barang dan peralatan, sekaligus juga penerimaan atau pendapatan yang timbul darinya diserahkan kepada pihak lain dalam jangka waktu tertentu diberi hak untuk mengoperasikan, memeliharanya serta untuk mengambil manfaat ekonomi guna menutup sebagai ganti biaya pembanguna proyek yang bersangkutan dan memperoleh keuntungan yang diharapkan.
Salah satu bentuk kerja sama Pemerintah dengan pihak swasta dalam bentuk hubungan kontraktual adalah kontrak BOT (Built, Operation, Transfer). Maraknya kontrak BOT yang dilakukan oleh Pemerintah didasarkan pada semakin besarnya tuntutan dan perkembangan kebutuhan masayarakat, sementara modal tidak tersedia. Dalam kondisi ini, Pemerintah pada umumnya tidak memiliki modal, kecuali aset tanah dan adanya kesulitan dalam melaksanakan pembangunan.

BOT merupakan salah satu alternatif pembiayaan proyek yang dapat dilakukan dengan mengundang pihak swasta untuk berpartisipasi dalam pengadaan proyek pemerintah. Dengan BOT, sektor swasta berperan dalam hal mendesain, menyedia- kan keuangan, membangun dan mengoperasikan fasilitas untuk kemudian akhirnya, setelah masa konsesi tertentu, kepemilikan ditransfer kepada pemilik tanah atau pemerintah. Oleh karena itu, BOT dapat dimaknai sebagai teknik untuk mengembangkan proyek-proyek infra- struktur dengan menggunakan inisiatif dan pendanaan dari pihak swasta

BOT memiliki masa konsesi yaitu masa bagi pihak swasta untuk mengoperasikan proyek selama beberapa tahun, biasanya ditentukan selama 20 (dua puluh) tahun, dan selama waktu tersebut dapat memungut hasil atau imbalan jasa karena membangun proyek tersebut.

Kontrak BOT merupakan perjanjian antara 2 (dua) pihak, yaitu Pemerintah dan pihak swasta. Pihak Pemerintah selaku pihak pertama menyerahkan penggunaan tanah miliknya untuk di atasnya didirikan suatu bangunan komersial oleh pihak kedua (investor). Pihak kedua berhak mengoperasikan atau mengelola bangunan komersial untuk jangka waktu tertentu dengan memberikan fee (atau tanpa fee) kepada pihak pertama, dan pihak kedua wajib mengembalikan tanah

6 Ibid. 
beserta bangunan komersial di atasnya dalam keadaan dapat dan siap dioperasikan kepada pihak pertama setelah jangka waktu operasional tersebut berakhir.

lain:

Objek dalam kontrak BOT, antara

a. Bidang usaha yang memerlukan suatu bangunan dengan atau tanpa teknologi tertentu yang merupakan komponen utama dalam usaha tersebut sebagau bangunan komersial.

b. Bangunan komersial tersebut dapat dioperasikan dalam jangka waktu relatif lama, untuk tujuan:

1) Pembangunan prasarana umum, seperti jalan tol, pembangkit listrik, sistem telekomunikasi, pelabuhan peti kemas dan sebagainya.

2) Pembangunan properti, seperti pusat perbelanjaan, hotel, apartemen dan sebagainya.

3) Pembangunan prasarana produksi, seperti pembangunan pabrik untuk menghasilkan produk tertentu.

\section{HAM dalam Undang-Undang Dasar Negara Republik Indonesia Tahun 1945}

Dalam kepustakaan berbahasa Inggris ditemukan berbagai istilah seperti: "natural rights", "human rights", dan "fundamental rights"; dalam kepustakaan berbahasa Belanda terdapat istilah-istilah seperti grondrechten, mensen- rechten, rechten van den mens" dan "fundamentele rechten". Dalam kepustakan berbahasa Indonesia terdapat istilah-istilah seperti: "hak-hak asasi manusia", "hak-hak kodrat", "hak-hak dasar" yang sering diberi imbuhan manusia sehingga menjadi "hak-hak dasar manusia".?

Istilah "natural rights" berasal dari pikiran-pikiran "natural law" yang berperanan pada abad ke 17. Apa yang merupakan hak menurut konsep ini

7 Philipus M. Hadjon, Op. Cit., h. 33-34 adalah "what is nature" yaitu apa yang diletakkan Allah terhadap setiap insan manusia. Istilah "human rights" yang populer pada abad ke 18 adalah perkembangan dari konsep "natural rights" dalam watak yang sekular, rational, universal, individual, demokratik dan radikal. Dalam konsep "natural rights" dikatakan "setiap manusia adalah sama di hadapan Tuhan", maka dalam watak yang sekular dikatakan "setiap manusia adalah sama di hadapan hukum", tetapi dalam menjelaskan konsep "persamaan di hadapan hukum" yang pada hakekatnya "sekular" itu, orang kembali lagi kepada pemikiranpemikiran "natural law" dengan "theonomic thinking". Bagi konsep "human rights", apa yang menjadi hak adalah "what is human". "Fundamental rights" meliputi, baik "legal right" maupun "moral right". Hak-hak tertentu dikatakan fundamental bukan karena hakhak tersebut konstitusional sifatnya, artinya ditempatkan dalam konstitusi atau di dalam "basic rules". 8

Dalam Pasal 1 angka 1 UndangUndang Nomor 39 Tahun 1999 tentang Hak Asasi Manusia (Lembaran Negara Republik Indonesia Tahun 1999 Nomor 165, Tambahan Lembaran Negara Republik Indonesia Nomor 3886), 'Hak Asasi Manusia adalah seperangkat hak yang melekat pada hakikat keberadaan manusia sebagai makhluk Tuhan Yang Maha Esa dan merupakan anugerah-Nya yang wajib dihormati, dijunjung tinggi, dan dilindungi oleh negara, hukum, pemerintah, dan setiap orang demi kehormatan serta perlindungan harkat dan martabat manusia". Hal ini berarti bahwa manusia yang diciptakan oleh Tuhan Yang Maha Esa dengan seperangkat hak yang menjamin derajatnya sebagai manusia.

"Fundamental rights" meliputi baik "legal right" maupun "moral right". "fundamental rights" sebagaimana

\footnotetext{
8 Ibid., h. 35
} 
dicantumkan dalam Undang-Undang Dasar Negara Republik Indonesia. "Fundamental rights" dapat dikatakan sebagai "constitutional rights" atau "the citizen's constitutional rights". Adanya "the citizen's constitutional rights" didasarkan pada pertimbangan bahwa hak-hak dasar sebagaimana diatur dalam Undang-Undang Dasar Negara Republik Indonesia ditujukan pada warga negara Indonesia.

Hak asasi manusia yang telah mendapatkan jaminan konstitusional dalam Undang-Undang Dasar Negara Republik Indonesia Tahun 1945, antara lain:

(1) Setiap orang berhak untuk hidup serta berhak mempertahankan hidup dan kehidupannya (Pasal 28A);

(2) Setiap orang berhak membentuk keluarga dan melanjutkan keturunan melalui perkawinan yang sah (Pasal 28B ayat (1));

(3) Setiap anak berhak atas kelangsungan hidup, tumbuh dan berkembang serta berhak atas perlindungan dari kekerasan dan diskriminasi (Pasal 28B ayat (2));

(4) Setiap orang berhak mengembangkan diri melalui pemenuhan kebutuhan dasarnya, berhak mendapat pendidikan dan memperoleh manfaat dari ilmu pengetahuan dan teknologi, seni dan budaya, demi meningkatkan kualitas hidupnya dan demi kesejahteraan umat manusia (Pasal 28C ayat (1));

(5) Setiap orang berhak untuk memajukan dirinya dalam memperjuangkan haknya secara kolektif untuk membangun masyarakat, bangsa dan negaranya (Pasal 28C ayat (2));

(6) Setiap orang berhak atas pengakuan, jaminan, perlindungan, dan kepastian hukum yang adil serta perlakuan yang sama dihadapan hukum (Pasal 28D ayat (1));

(7) Setiap orang berhak untuk bekerja serta mendapat imbalan dan perlakuan yang adil dan layak dalam hubungan kerja (Pasal 28D ayat (2));

(8) Setiap warga negara berhak memperoleh kesempatan yang sama dalam pemerintahan (Pasal 28C ayat (3));

(9) Setiap orang berhak atas status kewarganegaraan (Pasal 28C ayat (4));

(10) Setiap orang berhak memeluk agama dan beribadat menurut agamanya, memilih pendidikan dan pengajaran, memilih pekerjaan, memilih kewarganegaraan, memilih tempat tinggal di wilayah negara dan meninggalkannya, serta berhak kembali (Pasal 28E ayat (1));

(11) Setiap orang atas kebebasan menyakini kepercayaan, menyatakan pikiran dan sikap, sesuai dengan hati nuraninya (Pasal 28E ayat (2));

(12) Setiap orang berhak atas kebebasan berserikat, berkumpul dan mengeluarkan pendapat (Pasal 28E ayat (3));

(13) Setiap orang berhak untuk berkomunikasi dan memperoleh informasi untuk mengembangkan pribadi dan lingkungan sosialnya, serta berhak untuk mencari, memperoleh, memiliki, menyimpan, mengolah, dan menyampaikan informasi dengan menggunakan segala jenis saluran yang tersedia (Pasal 28F)

(14) Setiap orang berhak atas perlindungan diri pribadi, keluarga, kehormatan, martabat, dan harta benda yang dibawah kekuasaannya, serta berhak atas rasa aman dan perlindungan dari ancaman ketakutan untuk berbuat atau tidak berbuat sesuatu yang merupakan hak asasi (Pasal 28G ayat (1));

(15) Setiap orang berhak untuk bebas dari penyiksaan dan perlakuan yang merendahkan derajat martabat manusia dan berhak memperoleh suaka politik dari negara lain (Pasal $28 \mathrm{G}$ ayat $(2))$; 
(16) Setiap orang berhak hidup sejahtera lahir dan batin, bertempat tinggal, dan mendapatkan lingkungan hidup baik dan sehat serta berhak memperoleh pelayanan kesehatan (Pasal 28H ayat (1));

(17) Setiap orang mendapat kemudahan dan perlakuan khusus untuk memperoleh kesempatan dan manfaat yang sama guna mencapai persamaan dan keadilan (Pasal $28 \mathrm{H}$ ayat (2));

(18) Setiap orang berhak atas jaminan sosial yang memungkinkan pengembangan dirinya secara utuh sebagai manusia yang bermartabat (Pasal 28H ayat (3));

(19) Setiap orang berhak mempunyai hak milik pribadi dan hak milik tersebut tidak boleh diambil alih secara sewenang-wenang oleh siapapun (Pasal 28H ayat (4));

(20) Hak untuk hidup, hak untuk tidak disiksa, hak kemerdekaan pikiran dan hati nurani, hak beragama, hak untuk tidak diperbudak, hak untuk diakui sebagai pribadi di hadapan hukum, dan hak untuk tidak dituntut atas dasar hukum yang berlaku surut adalah hak asasi manusia yang tidak dapat dikurangi dalam keadaan apa pun (Pasal 28I ayat (1));

(21) Setiap orang berhak bebas atas perlakuan yang bersifat diskriminatif atas dasar apa pun dan berhak mendapatkan perlindungan terhadap perlakuan yang bersifat diskriminatif itu (Pasal 28I ayat (2)); dan

(22) Identitas budaya dan hak masyarakat tradisional dihormati selaras dengan perkembangan zaman dan peradaban (Pasal 28I ayat (3)).

\section{Pemenuhan HAM Dalam Kontrak BOT}

Pasal 28H ayat (1) di atas, pemenuhan hak asasi manusia untuk mendapatkan lingkungan hidup yang baik dan sehat merupakan komponen hak asasi manusia yang berkaitan dengan pemanfaatan bangunan. Kebutuhan akan bangunan merupakan wujud pelayanan publik yang dilakukan oleh pemerintah dalam tujuan memajukan kesejateraan umum. Tetapi terkadang pemerintah kekurangan dana untuk membangun dan menyediakan sebuah gedung dengan semua sarana dan fasilitasnya.

Tetapi karena pemerintah adalah pelayan masyarakat, maka pemerintah berkewajiban memenuhi kebutuhan tersebut. Untuk memenuhi kebutuhan tersebut, maka pemerintah dapat mengundag pihak swasta untuk bekerjasama menamkan modalnya atas bangunan yang dibutuhkan.

Proses pelaksanaan kerja sama antara Pemerintah dengan pihak swasta salah satunya adalah melalui sistem BOT, yang dilaksanakan berdasarkan Peraturan Menteri Dalam Negeri Nomor 17 Tahun 2007 tentang Pedoman Teknis Pengelolaan Barang Milik Daerah. Sistem BOT terkait dengan Peraturan Menteri Dalam Negeri ini dikarenakan pemerintah memiliki aset berupa tanah yang dijadikan sebagai dasar adanya kegiatan kerja sama pembangunan infrastruktur yang memiliki nilai komersial.

BOT biasanya diterapkan pada proyek pemerintah yang berskala besar dan bernilai komersial yang dalam studi kelayakan pengadaan barang dan peralatan, pembiayaan dan pembangunan serta pengoperasiannya, sekaligus juga penerima- an atau pendapatan yang ditimbul darinya diserahkan kepada pihak swasta. Pihak swasta diberikan hak untuk membnagun, mengoperasikan memeliharanya serta untuk mengambil manfaat ekonominya guna menutup sebagai ganti biaya pembangunan proyek yang bersangkutan dan memperoleh keuntungan yang diharapkan.

Kontrak BOT merupakan perjanjian antara 2 (dua) pihak, antara lain pihak pemerintah dan pihak swasta. Pihak pemerintah menyerahkan tanah 
miliknya yang merupakan aset negara untuk di atasnya didirikan suatu bangunan komersial oleh pihak swasta. Kemudian pihak swasta dimaksud berhak untuk mengoperasikan atau mengelola bangunan komersial untuk jangka waktu tertentu dengan memberikan fee atau tanpa fee kepada pemerintah. Pada saat waktu yang ditentukan berakhir, pihak swasta mengembalikan tanah dan bangunan komersial di atasnya dalam keadaan dapat dan siap dioperasionalkan kepada pemerintah.

Kontrak BOT dibagi dalam 3 (tiga) tahap, antara lain tahap pembangunan (Built); tahap pengoperasian (Operate), dan tahap penyerahan (Transfer). Penulisan ini difokuskan pada tahap penyerahan (transfer). Pada tahap ini seringkali menimbulkan permasalahan hukum terkait dengan penyerahan tanah dan bangunan komersial di atasnya. Permasalahan hukum yang terjadi dimana nilai ekonomi dari bangunan komersial yang tidak sesuai lagi dengan kondisi saat pembangunan. Secara hukum, hak dan kewajiban para pihak dalam hal ini pemerintah dan pihak swasta harus dijamin pada ketiga tahapan dimaksud, baik tahap pembangunan, tahap pengoperasian dan tahap penyerahan.

Kontrak BOT sering terjadi antara pemerintah daerah dan pihak swasta untuk bangunan pasar. Dalam hal ini pemerintah daerah memberikan kesempatan kepada pihak swasta untuk mengoperasikan bangunan pasar dimaksud hingga masa waktu yang ditentukan. Kenyataannya dalam proses penyerahan bangunan pasar mengalami masalah bahwa kualitas bangunan pasar dimaksud sudah tidak sesuai lagi dengan layaknya suatu bangunan pasar. Secara hukum hal ini belum terlalu banyak diatur dalam Kontrak BOT yang dapat mengikat para pihak.

Terkait dengan itu, bangunan pasar merupakan fasilitas publik yang digunakan untuk masyarakat dalam melakukan transaksi kebutuhan pokok hari-hari. Dengan adanya kondisi bangunan pasar hasil BOT yang sudah tidak sesuai lagi dengan fungsi peruntukkannya, tentu menimbulkan permasalahan baru bagi masyarakat. Permasalahan ini terkait dengan hak masyarakat untuk mendapat fasilitas publik yang nyaman dan memenuhi kualifikasi kualitas bangunan baik jaminan keamanan, keselamatan dan kesehatan masyarakat.

Kondisi bangunan gedung pasar yang tidak layak lagi untuk digunakan setelah sebelumnya telah dioperasikan atau dimanfaatkan oleh pihak swasta merupakan kerugian bagi pemerintah daerah maupun bagi masyarakat pengguna bangunan tersebut. Sebagai pengguna bangunan pasar yang merupakan fasilitas publik, masyarakat berhak untuk mendapatkan jaminan kualitas bangunan gedung.

Pemerintah daerah bertanggungjawab untuk meningkatkan kualitas bangun- an gedung dimaksud untuk kepentingan masyarakat. Apabila pemerintah lalai untuk melakukan revitalisasi terhadap bangunan dimaksud, maka kelalaian tersebut merupakan bentuk pelanggaran terhadap hak asasi manusia yang dimiliki oleh masyarakat selaku pengguna bangunan gedung pasar.

\section{PE N U T U}

Pemenuhan hak asasi manusia ini didasarkan pada Pasal $28 \mathrm{H}$ ayat (1) yang menyebutkan bahwa "Setiap orang berhak hidup sejahtera lahir dan bathin, bertempat tinggal, dan mendapatkan lingkungan hidup baik dan sehat serta berhak memperoleh pelayanan kesehatan". Mengacu dari ketentuan Pasal $28 \mathrm{H}$ ayat (1) di atas, pemenuhan hak asasi manusia untuk mendapatkan lingkungan hidup yang baik dan sehat merupakan komponen hak asasi manusia 
yang berkaitan dengan pemanfaatan bangunan gedung pasar yang layak untuk digunakan. Untuk memenuhi tugas pelayanan publiknya, maka ketika pemerintah tidak memiliki dana atau kekurangan dana untuk menyediakan bangunan yang dibutuhkan oleh masyaraka, maka pemerintah dapat memberikan kesempatan kepada pihak swasta untuk membangun bangunan dan mengelolanya. Dan setelah masa pengelolaan tersebut selesai, maka pihak swasta berkewajiban mengembalikan bangunan beserta seluruh saran dan fasilitas yang dibangun kembali kepada pemerintah sebagai aset daerah. Konsekuensi hukum dari tidak dipenuhinya pemenuhan hak asasi ini, maka pemerintah daerah telah lalai dalam melaksanakan tugas utamanya dalam pelayanan publik maupun terjadinya pelanggaran hak asasi manusia

\section{DAFTAR PUSTAKA}

Philipus M. Hadjon, 2007, Perlindungan Hukum Bagi Rakyat di Indonesia, Sebuah Studi tentang PrinsipPrinsipnya dan Penanganannya oleh Pengadilan Dalam Lingkungan Peradilan Umum dan Pembentukan Peradilan Administrasi, Edisi Khusus, Penerbit Peradaban, Cet. Pertama

Yohanes Sogar Simamora, 2009, Hukum Perjanjian - Prinsip Hukum Kontrak Pengadaan Barang dan Jasa Oleh Pemerintah, LaksBang PRESSindo, Yogyakarta.

Juoro Umar, 1997, Peran Swasta dan Kepentingan Masyarakat Dalam Pembangunan Infrastruktur, Koperasi Jasa Profesi, Jakarta.

Munir Fuady, 1995, Hukum Tentang Pembiayaan Teori dan Praktek, PT. Citra Aditya Bakti, Bandung 